\title{
THE IMPORTANCE OF THE ORGANIZATION OF PHYSICAL CULTURAL ACTIVITIES BASED ON ADVANCED PEDAGOGICAL TECHNOLOGIES
}

Rasul Hamrakulov

Candidate Of Pedagogical Sciences, Associate Professor, Fergana State University, Fergana, Uzbekistan

\section{ABSTRACT}

In our country, consistent measures are being taken to develop physical culture and sports, create the necessary conditions and infrastructure to promote a healthy lifestyle, especially among young people, to ensure the country's worthy participation in international sports arenas. It should be noted that the strategy of scientific and pedagogical innovative education in the field of physical culture and sports is based on solving interrelated issues.

KEYWORDS:- Innovation, pedagogy, physical education, pedagogical skill, pedagogical efficiency, physical education.

\section{INTRODUCTION}

Human life and health are the greatest social wealth. This raises the question of forming a healthy lifestyle for the family, school, places of upbringing and human development. The health of a nation is also naturally addressed through a healthy lifestyle.

The way of life itself means that a person acquires the living conditions necessary for survival. Depending on the method of acquisition, it can be divided into a healthy lifestyle and an unhealthy lifestyle, as well as the formation of the formation of a healthy lifestyle, its relationship with other disciplines, the coordination of its goals and objectives.

Processes of profound changes, consistent reform and liberalization of all aspects of political and socio-economic life, democratic renewal and modernization of our society are rapidly developing in our country. At the same time, the enormous tasks set and consistently carried out on the way to building a strong civil society create a solid foundation.

\section{Methods}

The socio-economic, spiritual and educational reforms carried out in the country are aimed at solving the issues provided for by the Strategy of Actions for the Development of the Republic of Uzbekistan. One of the important aspects of this is the training of highly qualified personnel with high moral and ethical potential.

For this, it is necessary to organize the educational process of educational institutions that train highly qualified specialists in accordance with the requirements of the time, to increase the effectiveness of educational work, to organize its directions on the basis of advanced pedagogical technologies. As the President of the 
CURRENT RESEARCH JOURNAL OF PEDAGOGICS 2(5): 114-119, May

2021 DOI: https://doi.org/10.37547/pedagogics-crjp-02-05-20

ISSN 2767-3278

(C)2021 Master Journals

\section{Crossref do) 81 Google}

Accepted 25th May, 2021 \& Published 31 ${ }^{\text {th }}$ May, 2021

Republic Sh.M. Mirziyoyev noted: "Today, when we think about the rapidly changing life, the solution of complex and important issues facing us, the solution is through education, modern knowledge of youth, high spirituality. and we are once again convinced that this is connected with the formation on the basis of enlightenment" [1, 448].

Physical education is an integral part of the national culture of the peoples of the Republic of Uzbekistan, an important tool for physical and spiritual development. Only when physical education is based on a clear system can a predetermined result be achieved. The system of physical education is understood as the community of principles, means, methods and forms of its organization of physical education in such a way that it corresponds to the goals and objectives of the all-round harmonious development of a member of society. Consequently, since the decision of the basis of all reforms depends on education, it is necessary to organize it on the basis of modern pedagogical technologies. Indeed, advanced pedagogical technologies have entered the life of education since the second half of the twentieth century as a socio-historical necessity and a spiritualpedagogical phenomenon and have served to increase the effectiveness of teaching and learning as a pedagogical mechanism introducing young people to the problems of science.

In the process of physical education, as in other areas of education, purposeful activity does not always correspond to the planned result. In physical education, training results require consideration of how planned exercise for a young athlete or physical fitness affects his body, does not live up to expectations. This interferes with comprehensive harmonious development and undermines athletic performance. Therefore, before the teacher and the coach, the need to be able to see far away, to make predictions will be cross-cutting. The solution to this problem should be carried out in the system of training educated, knowledgeable and loving professionals. Accordingly, they should be able to positively solve goals and objectives, and they should consider it their main duty from childhood to raise a physically healthy and spiritually healthy child.

\section{Results AND DISCUSSIONS}

In modern teacher education, professional culture is seen as a value.

There:

considering the conceptual and educational directions, goals and objectives of the national training program;

creation of new programs, textbooks, teaching aids, updating, revision, modernization of recommendations;

the scientific and pedagogical system is focused on the formation of a scientifically grounded systemic pedagogical culture.

The government policy in the field of education establishes the priority of modern education, which is to improve the training of future teachers in the context of a modern humanitarian concept. First of all, the work on the formation of pedagogical culture among future teachers, in particular, the culture of pedagogical communication, should be improved. In this regard, in the educational process, special attention is paid to the personality of the future specialist, his professional and personal training, especially intellectual and creative, activity-practical and socio-communicative, the priority of his professional culture - pedagogical dialogue. In the face of higher pedagogical education, the most important task should be to prepare future teachers for future pedagogical activities through the formation of a culture of communication. "Any pedagogically correct activity affects the 
CURRENT RESEARCH JOURNAL OF PEDAGOGICS 2(5): 114-119, May

2021 DOI: https://doi.org/10.37547/pedagogics-crjp-02-05-20

ISSN 2767-3278

(C)2021 Master Journals

\section{Crossref do) 81 Google}

Accepted 25th May, 2021 \& Published 31 th May, 2021

mental and volitional development of a person. This means that as the child grows up, his activity changes in form and content" $[2,35]$.

"Physical culture is a set of achievements in the creation and rational use of special means, methods, conditions for the purposeful implementation of the physical development of members of society"[3,67], physical education classes in an organized pedagogical process in physical education. institutions based on traditional and non-traditional forms of education. Because training is organized according to certain laws, based on the requirements and needs of the time.

These laws are described in the theory of pedagogy as follows:

a) the law of determination of learning by social need;

b) the pedagogical state in which learning takes place - the law of dependence on conditions;

c) the law of interdependence of educational, upbringing and developmental processes that make up a single pedagogical learning process;

d) the legality of teaching in a single pedagogical process with general and professional orientation of students;

e) the legitimacy of the need to implement the content, forms, methods, means of general and interdisciplinary disciplines in an integrated pedagogical process.

Since physical education classes consist of theoretical and practical parts, they are conducted in the form of lectures, seminars, trainings, additional classes, and so on. This is carried out in the form of monologue speech, dialogical speech, planned conversation, exchange of ideas in a monologue, discussion, question-answer, role-playing games, physical training.
Using this technology, classes are organized on the basis of advanced pedagogical technologies in the form of competitions, problem modules, integrated collaborative learning, computer learning, differentiated and active learning, called non-traditional forms of education. Classes based on advanced pedagogical technologies are mainly aimed at increasing student activity, in which almost all students participate as subjects of learning. In such classes, methods such as "brainstorming", "quick storming of thoughts", "cluster", "syncwine", "happy event", "creative report", "decision tree" are used, which will serve to increase student activity and develop them creative and independent thinking. Proceeding from this, the use of advanced pedagogical technologies in the process of physical education includes didactic systems, such as a clear definition of learning goals based on the content of training, guaranteeing results, building the educational process based on guaranteed results. Another feature of the use of pedagogical technology in physical education is that it stimulates and develops students' interest in physical culture and sports competitions on the basis of strengthening and strengthening exercises, physical fitness exercises, general motor-forming exercises that express goals. physical culture.

\section{Conclusion}

In conclusion, we can say that the physical maturity and improvement of ourselves and our children in the way of life of our ancestors is at a high level in the education system. Eventually he rose to the level of values. From this it follows that with the timely observance of the above requirements in the process of the pedagogical process, physical culture is formed, and at the same time the effectiveness of the process of physical education increases. 
CURRENT RESEARCH JOURNAL OF PEDAGOGICS 2(5): 114-119, May

2021 DOI: https://doi.org/10.37547/pedagogics-crjp-02-05-20

ISSN 2767-3278

(C)2021 Master Journals

Crossref do: 81 Google

Accepted 25 ${ }^{\text {th }}$ May, 2021 \& Published 31 ${ }^{\text {th }}$ May, 2021

\section{REFERENCES}

1. Mirziyoev Sh.M. The consent of our people is the highest value given to our activities. Tashkent: "Uzbekistan", 2018.

2. Mavlonova R. et al. Pedagogy: a textbook for students of faculties of primary education methods of higher education, students of pedagogical lyceums and colleges. Tashkent, "Teacher", 2001.

3. Norqobilov M.N., Mirkhodjaeva Z.S., Mahmudov V.V. Pedagogical approaches to inculcating a healthy lifestyle in the minds of students in physical culture and sports. Monograph. Tashkent, 2019.

4. Pedagogy. Textbook for higher education institutions. Edited by M. Tokhtakhojaeva. Tashkent: "Teacher" 2008.

5. Voinova M.G. Pedagogical technologies and pedagogical skills: Textbook. - Tashkent, 2005.

6. Tuxtanazarov, I. U., \& Maxmutaliyev, A. M. (2020). SCIENTIFIC AND METHODOLOGICAL PROBLEMS OF WRESTLING DEVELOPMENT. Theoretical \& Applied Science, (1), 781-785.

7. Khakimov N.H., Ganiyev B.S., THE ROLE OF STUDYING THE STRATEGY OF ACTION IN CHOOSING A PROFESSIONAL DIRECTION (TAKING INTO ACCOUNT THE FORMATION OF ENTREPRENEURIAL QUALITIES) IN STUDENTS // Scientific Bulletin of Namangan State University. - Namangan, 2019. № 7 - P. 296-303.

8. Forming a healthy lifestyle in students. D.J.Sharipova, G.S.Fuzailova, M.Turkmenova, D.Zufarova. Fergana, 2010.

9. Physical culture of a healthy lifestyle. Sh.Xonkeldiev, A.Abdullaev, Yu.M.Kasach, A.T.Xasanov, M.M.Yuldashev. Fergana, 2010.

10. Ganiev, B. (2015). Business-Ethics in Islam.
Theoretical \& Applied Science, (7), 177-179.

11. Ganiyev B.S. EDUCATION-PRIORITY SPHERE OF REFORM IN THE CONDITIONS OF A NEW STAGE OF DEVELOPMENT // ELECTRONIC JOURNAL OF ACTUAL PROBLEMS OF MODERN SCIENCE, EDUCATION AND TRAININ - Xorezm. 2020. № 2 - P. 28-39.

12. Karimov, U., \& Kasimov, I. (2018). THE IMPORTANCE OF MODERN INFORMATION TECHNOLOGIES IN DEVELOPMENT OF DISTANCE EDUCATION. In Перспективные информационные технологии (ПИТ 2018) (pp. 1186-1187).

13. Karimov, U., \& Ergasheva, D. (2020). EDUCATIONAL ISSUES IN THE PERIOD OF AMIR TEMUR AND TEMURIDS. Теория и практика современной науки, (5), 18-20.

14. Каримова, Г. Й. (2018). РОЛЬ КОНСТИТУЦИИ В ПОСТРОЕНИИ ПРАВОВОГО ГОСУДАРСТВА И ГРАЖДАНСКОГО ОБЩЕСТВА. Теория и практика современной науки, (2), 161163.

15. Abdurakhmonov, S. K. (2021). The Importance Of A Healthy Lifestyle In Achieving Physical Perfection. The American Journal of Applied sciences, 3(03), 42-47.

16. Каримов, У. (2017) ИНФОКОМТЕХНОЛОГИИ (ИКТ) ФОРМИРОВАНИЕ ДУХОВНЫХ ХАРАКТЕРИСТИК ЛИЧНОСТИ. In Перспективные информационные технологии (ПИТ 2017) (рp. 1160-1163).

17. Tuxtanazarov, I. U., \& Maxmutaliev, A. M. (2020). SOCIO-PEDAGOGICAL FUNCTION OF SPORT IN THE SPIRITUAL PERFECTION OF YOUTH. Scientific Bulletin of Namangan State University, 2(1), 367-372.

18. I.Azimov. Sports physiology. Tashkent, 1993.

19. Karimov, U., Kaxarov, S., Yokubjonov, S., \& 
CURRENT RESEARCH JOURNAL OF PEDAGOGICS 2(5): 114-119, May

2021 DOI: https://doi.org/10.37547/pedagogics-crjp-02-05-20

ISSN 2767-3278

(C)2021 Master Journals

Crossref doi 81 Google

Accepted 25 $5^{\text {th }}$ May, 2021 \& Published 31 ${ }^{\text {th }}$ May, 2021

Ziyodov, D. (2018). USING NEW INFORMATION TECHNOLOGIES IN DISTANCE LEARNING SYSTEM. In HOBAЯ ПРОМЫШЛЕННАЯ РЕВОЛЮЦИЯ В ЗЕРКАЛЕ СОВРЕМЕННОЙ НАУКИ (рр. 911).

20. Abdurakhmonova, M. M., ugli Mirzayev, M. A., Karimov, U. U., \& Karimova, G. Y. (2021). Information Culture And Ethical Education In The Globalization Century. The American Journal of Social Science and Education Innovations, 3(03), 384-388.

21. Karimov, U., \& Abdurakhmon, A. (2017). INNOVATIVE INFORMATION TECHNOLOGY IN EDUCATION. Форум молодых ученых, (5), 9-12.

22. Mehmonov, R., \& Parpiev, O. (2020). PEDAGOGICAL REQUIREMENTS FOR PHYSICAL EDUCATION TEACHERS. Theoretical \& Applied Science, (5), 758-761.

23. Mehmonov, R., \& Parpiev, O. (2020). THE PROCESSES OF ORGANIZATION OF GENERAL AND SPECIAL TRAINING OF ATHLETES. Теория и практика современной науки, (5), 38-40.

24. Каримов, У., Хакимова, Д., \& Халилов, Л. (2018). ИНФОРМАЦИОННОЕ И КОММУНИКАЦИОННОЕ ТЕХНОЛОГИИ ВЛИЯНИЕ НА ОБРАЗОВАНИЕ В ТЕХНИЧЕСКОМ ОБСЛУЖИВАНИЕ. Мировая наука, (10), 193-197.

25. Yuldashev, I. A. (2020). PEDAGOGICAL BASES OF FORMATION OF SOCIAL ACTIVITY IN PEDAGOGICAL SCIENCES. Теория и практика современной науки, (5), 67-69.

26. Yuldashev, I., \& Toshboltaeva, N. I. (2020). ANALYSIS OF PERSONALITY TRAITS IN ATHLETE ACTIVITIES. In Психологическое здоровье населения как важный фактор обеспечения процветания общества (рр. 72-74).
27. Yuldashev, S. U. (2019). THE ROLE OF THE FUNCTION OF STABILIZATION AND DEVELOPMENT OF SOCIETY IN SCIENTIFIC MANAGEMENT (AS SOCIO-CULTURAL TECHNOLOGY). Scientific Bulletin of Namangan State University, 1(6), 255-259.

28. Normatova D. E. PECULIARITIES OF ANTHROPOCENTRISM AND HUMANISM OF THE SOCIO-PHILOSOPHICAL THOUGHT OF WESTERN EUROPE IN THE ERA OF RENAISSANCE //Scientific Bulletin of Namangan State University. - 2019. - T. 1. №. 5. - C. 168-173.

29. Yuldashev, S. U. (2019). TECHNOLOGY OF SOCIAL AND CULTURAL PROJECTION IN SCIENTIFIC MANAGEMENT OF SOCIETY. Theoretical \& Applied Science, (11), 621-623.

30. Yuldashev, S. (2020). Socio-Cultural Technologies in Uzbekistan: History and Now. International Journal of Progressive Sciences and Technologies, 18(1), 171-173.

31. Normatova D. E. THE SOCIAL AND MORAL VIEWS OF MICHELLE ECKEM DE MONTEN //Scientific Bulletin of Namangan State University. - 2019. - T. 1. - №. 10. - C. 184187.

32. Normatova, D. E. (2021). The Development Of Socio-Philosophical Thought In Western Europe On The Eve Of The End Of The Renaissance. The American Journal of Social Science and Education Innovations, 3(03), 371-377.

33. Dubrovskiy V.I. Sports medicine.- M .: Vladas, 1998.

34. Dubrovskiy V.I. Healthy lifestyle. -M .: 1999.

35. L.P.Matveev. Theory and methods of physical culture. Textbook. M .: 1991.

36. Ganiyev, B. S. (2020). EDUCATION-PRIORITY SPHERE OF REFORM IN THE CONDITIONS OF A NEW STAGE OF DEVELOPMENT. 
CURRENT RESEARCH JOURNAL OF PEDAGOGICS 2(5): 114-119, May

2021 DOI: https://doi.org/10.37547/pedagogics-crjp-02-05-20

ISSN 2767-3278

(C)2021 Master Journals

Crossref dof 81 Google

Accepted 25 $5^{\text {th }}$ May, 2021 \& Published 31 $1^{\text {th }}$ May, 2021

Central Asian Problems of Modern Science and Education, 2020(1), 106-111.

37. Parpiev, O. (2021). The Health-Oriented Principle of Physical Education. The American Journal of Applied sciences, 3(03), 22-27. 